\title{
EFFECTS OF VEGETATION SWITCH AND SUBSEQUENT CHANGE IN SOIL INVERTEBRATE COMPOSITION ON SOIL CARBON ACCUMULATION PATTERNS, REVEALED BY RADIOCARBON CONCENTRATIONS
}

\author{
Ayu Toyota ${ }^{1,2}$ - Ichiro Tayasu ${ }^{1}$ Reiji Fujimaki ${ }^{3}$ Nobuhiro Kaneko $^{3} \cdot$ Masao Uchida $^{4} \bullet$ \\ Yasuyuki Shibata ${ }^{4}$ Tsutom Hiura ${ }^{2}$
}

\begin{abstract}
Vegetation types strongly affect soil organic carbon (SOC) accumulation in the terrestrial ecosystem through multiple factors such as litter quality and soil biodiversity. However, the roles of soil fauna in SOC accumulation remain unclear. The objectives of this study were to (1) examine how changes in litter types and soil animal communities affect SOC accumulation in continuously forested or vegetation-switched forest areas; and (2) discuss the role of soil animals in SOC accumulation in forest ecosystems. We focused on soils that have accumulated on top of a volcanic ash layer in the $268 \mathrm{yr}$ since a volcanic eruption in 1739. The radiocarbon "bomb spike" in the late 1950 s and early 1960 s provides a unique isotopic signature of soil carbon age. We investigated the combined effects of litter quality and soil invertebrate function on soil ${ }^{14} \mathrm{C}$ accumulation patterns. To determine the effects of vegetation types on SOC accumulation, we selected 4 types of cool temperate forests, 2 of which had undergone a vegetation switch in about 1960 (conifer to broadleaved forest, CB; broadleaved forest to conifer, $\mathrm{BC}$ ), and 2 that had continuous forests (conifer forest, $\mathrm{CC}$; broadleaved forest, $\mathrm{BB}$ ). The $\Delta^{14} \mathrm{C}$ values at depth intervals in $\mathrm{CC}$ were consistent with the expected bomb ${ }^{14} \mathrm{C}$ profile. In contrast, $\Delta^{14} \mathrm{C}$ patterns in $\mathrm{BB}, \mathrm{BC}$, and $\mathrm{CB}$ differed from that of CC. Compared to $\mathrm{CC}, \Delta{ }^{14} \mathrm{C}$ values of the other sites showed relatively high ${ }^{14} \mathrm{C}$ concentrations even in deeper soil layers, which suggests the bomb-induced ${ }^{14} \mathrm{C}$ has been transported to a greater depth by soil animals. Current broadleaved forests (BB and $\mathrm{CB}$ ) had higher biomass of litter-feeding invertebrates than in current coniferous forests (CC and $\mathrm{BC}$ ). These results suggest that carbon from leaf litter was vertically translocated to deeper soil layers by the abundant soil invertebrates in broad-leaved forests. Disagreement with the expected soil profile in BC suggests that past vegetation (broadleaved forest) has affected the present SOC accumulation pattern.
\end{abstract}

\section{INTRODUCTION}

Storage and decomposition of soil organic carbon (SOC) are significant factors in the global carbon cycle because soil is the largest carbon reservoir in terrestrial ecosystems (Körner 2000). It is still difficult to estimate the global carbon cycle accurately because of uncertainty in soil carbon dynamics (Schimel 1995). Long-term decomposition studies are essential for understanding the dynamics of soil organic matter (SOM). In the CENTURY model, Parton et al. (1987) described the effect of soil temperature and moisture on decomposition rates. Townsend et al. (1995) and Trumbore et al. (1996) examined temperature effects on the turnover time of SOM along an elevation gradient. Their findings showed that climatic factors, such as temperature, have greater effects on the decomposition process than plant litter quality on a regional scale. On a local scale, however, decomposition rates are most strongly affected by litter types (Köchy and Scott 1997). However, knowledge of long-term litter decomposition processes is limited, and few studies have assessed the changes in SOC dynamics associated with litter quality.

Decomposition rates are linked with lignin and nitrogen content of leaf litter (Melillo et al. 1982). Leaf nitrogen content is generally higher in broadleaved species than in conifers (Berg and McClaugherty 2003). Differences in litter decomposition should affect the rate of SOC accumulation. Some studies have compared decomposition rates between forested and cropped or grassland

\footnotetext{
${ }^{1}$ Center for Ecological Research, Kyoto University, 509-3, 2, Hirano, Otsu, Shiga 520-2113, Japan.

${ }^{2}$ Tomakomai Research Station, Field Science Center for Northern Biosphere, Hokkaido University, Tomakomai, Hokkaido 053-0035, Japan. Present address: Institute of Soil Biology, Biology Centre, Academy of Sciences of Czech Republic, Na Sádkách 7, 37005 České Budějovice, Czech Republic. Corresponding author. Email: ayuty@upb.cas.cz.

${ }^{3}$ Soil Ecology Research Group, Yokohama National University, 79-7 Tokiwadai, Hodogaya, Yokohama 240-8501, Japan.

${ }^{4}$ National Institute for Environmental Studies, 16-2 Onogawa, Tsukuba, Ibaraki 305-8506, Japan.
} 
soils, focusing on the difference between $\mathrm{C}_{4}$ and $\mathrm{C}_{3}$ plants (e.g. Smith and Johnson 2004). Replacement of grasslands by woodlands has resulted in significant increases in landscape-scale ecosystem carbon stocks (Hibbard et al. 2003). In cool temperate mixed forests, the vegetation type can change from conifer to broadleaved forest (or vice versa) after disturbances such as typhoons, or as a result of artificial plantations (Hiura and Fujiwara 1999). Changes in the dominant tree species lead to changes in the quality and quantity of litter input. However, few studies have evaluated the effects of vegetation switches on SOC dynamics. The aim of this paper is to provide preliminary data on whether accumulation patterns of SOC differ after a vegetation switch, based on field investigations. The vegetation of the Tomakomai Experimental Forest (TOEF) in Hokkaido, Japan, is ideal for studying this topic, for the following reasons: (1) the period of SOC accumulation in soil is confined to the A horizon, because the A horizon has accumulated since the eruption of Mt Tarumae in 1739, and can be easily separated from the lower clastic pumice layer; and (2) recent carbon input can be identified because the tree species in each forest have been recorded at least for $60 \mathrm{yr}$, and the previous vegetation before the change was also qualitatively reported.

Several natural tracers, including carbon stable isotope ratio $\left(\delta^{13} \mathrm{C}\right)$ and ${ }^{14} \mathrm{C}$ concentrations have been used to estimate carbon dynamics. Aboveground nuclear testing in the late 1950s and early 1960 s led to significantly increased levels of ${ }^{14} \mathrm{C}-\mathrm{CO}_{2}$ in the atmosphere. Thus, the "post-maximumbomb" ${ }^{14} \mathrm{C}$ activities (1964 to the present) provide a natural isotopic signature. Because forest SOC is exclusively derived from $\mathrm{CO}_{2}$ assimilation by plant photosynthesis, the measurement of ${ }^{14} \mathrm{C}$ concentrations in SOC can provide information about when the fraction of organic carbon was supplied to SOC. Accumulation of SOC is the result of a balance between decomposition and litter supply. Several studies have calculated turnover time of SOC fractions based on their $\Delta^{14} \mathrm{C}$ values (e.g. Townsend et al. 1995; Trumbore 2000). Those studies were carried out assuming a steady-state decomposition process in the forest or pasture where no abrupt change in SOC accumulation, such as volcanic ash deposition, was observed.

Soil macroinvertebrates, such as earthworms and millipedes, clearly affect primary litter decomposition and SOC accumulation (e.g. Lavelle and Martin 1992; Wolters 2000; Toyota et al. 2006). Most terrestrial ecosystems contain abundant macroinvertebrates, in terms of both quantity and species diversity (Petersen and Luxton 1982). The soil invertebrate communities are associated with the accumulated plant litter (O layer) mass, which serves as food and habitat (Petersen and Luxton 1982; Takeda and Abe 2001). They directly contribute to 7-13\% of carbon mineralization in European coniferous forests (Schröter et al. 2003). Soil animal activity could result in transport of carbon throughout their burrows (Don et al. 2008). Because soil animals control litter decomposition and carbon transportation, their effects on the vertical distribution of SOC may be greater than those of plant litter quality. However, little is known about the roles of soil animals in SOC accumulation, because it is difficult to determine the soil faunal effects on the fate of SOC.

Carbon and nitrogen stable isotope ratios are now widely used in ecological research. The carbon isotope ratio $\left(\delta^{13} \mathrm{C}\right)$ has been used to trace carbon sources, whereas the nitrogen isotope ratio $\left(\delta^{15} \mathrm{~N}\right)$ indicates trophic level. Therefore, these ratios can be used to study the foodweb. Recent publications have described soil foodwebs using these ratios (Ponsard and Arditi 2000; Scheu and Falca 2000; Halaj et al. 2005; Tiunov 2007; Okuzaki et al. 2009). However, isotopic studies on soil foodwebs are still under development. In particular, the trophic level enrichment in $\delta^{15} \mathrm{~N}$ is still being debated (e.g. Eggers and Jones 2000).

Earthworms are one of the most prominent "ecosystem engineers" (Jones et al. 1994). Their ecological groupings have been characterized on the basis of their feeding habits as epigeic, endogeic, and anecic (Lavelle 1988). Epigeic species are litter-dwelling, they feed on fresh organic materials, and 
they are important in the comminution of litter. Endogeic species live in the soil, moving horizontally through the upper mineral soil. They consume large quantities of soil and organic residues and some surface litter. Anecic species live in all strata of soil, normally in vertical burrows, and feed on and bury surface litter (Lavelle et al. 1997; Edwards 1998). Several studies have indicated that detritivores (humivores or soil-feeders), which feed on highly decomposed materials, have higher $\delta^{15} \mathrm{~N}$ values (Schmidt et al. 1997; Tayasu et al. 1997); thus, the values can be used to differentiate the feeding habits of soil fauna along the "humification gradient" (i.e. state of decay of plant material, sensu Tayasu et al. 1997). Tayasu et al. (2002) first demonstrated the applicability of ${ }^{14} \mathrm{C}$ in termites and used the ${ }^{14} \mathrm{C}-\mathrm{CO}_{2}$ record to estimate the "carbon retention" of the food. Hyodo et al. (2006) defined this value as the "diet age." The diet age of a consumer can be defined as the time elapsed since the carbon in its diet was fixed from atmospheric $\mathrm{CO}_{2}$ by primary producers. Briones et al. (2005) extensively measured $\Delta^{14} \mathrm{C}$ values of earthworms, and, after a seminal study by Scharpenseel et al. (1989), suggested that these could be applied to ecological groupings. Hyodo et al. (2008) showed that diet ages show a positive relationship with $\delta^{15} \mathrm{~N}$ values, suggesting that carbon turnover is related to decomposition processes. The diet age of soil fauna is an indicator of "active carbon" in soils. Because the carbon age, which is calculated by ${ }^{14} \mathrm{C}$ concentration in earthworms, indicates their functional position in the decomposition process, we can discuss the effects of earthworm activities on organic carbon by comparing ${ }^{14} \mathrm{C}$ concentrations between earthworms and their food resources.

We hypothesized that a change in tree species (a "vegetation switch") would affect the animal community, resulting in changes in SOC accumulation. We evaluated how a vegetation switch and the soil invertebrate composition affect SOC accumulation in the forest ecosystem. The objectives of this study were (1) to evaluate the relationship between the vertical distribution of SOC and vegetation type, (2) to investigate whether soil invertebrate composition responds to vegetation type, (3) to estimate how a vegetation switch affects the SOC accumulation, and (4) to discuss the function of invertebrates on the pattern of SOC accumulation by measuring stable isotope ratios and ${ }^{14} \mathrm{C}$ concentrations of soil invertebrates.

\section{METHODS}

\section{Site Description}

The study site was located in a cool temperate forest in the Tomakomai Experimental Forest of Hokkaido University, Japan $\left(42^{\circ} 4^{\prime} \mathrm{N}, 141^{\circ} 4^{\prime} \mathrm{E} ; 60-80 \mathrm{~m}\right.$ altitude; mean annual temperature $6.0^{\circ} \mathrm{C}$; mean annual precipitation $1450 \mathrm{~mm}$ ). The present vegetation developed after the large eruption of $\mathrm{Mt}$ Tarumae from 1667 to 1669 (Igarashi 1987). The organic layer (O layer) on the A layer was mainly composed of plant leaves mixed with twigs, and had an average thickness of $1.5-5 \mathrm{~cm}$. The soil at the A layer, below the $\mathrm{O}$ layer, had an average thickness of $8 \mathrm{~cm}$ with a color classification of 7.5YR 2/1 (Sakuma 1987), and its soil type was a volcanic Regosol (FAO et al. 1998). The parent material of the soil is clastic pumice and sand that was deposited by eruptions of Mt Tarumae in 1667 and 1739 (Fujiwara 1987). There is a spatial decoupling between the lower clastic pumice layer and upper layers (O layer and A layer), which have accumulated since the 1739 eruption of Mt Tarumae (Sakuma 1987). These soils are well drained. Vegetation types and history have been recorded for at least $60 \mathrm{yr}$ at this study site. To distinguish possible effects of a vegetation switch using the bomb${ }^{14} \mathrm{C}$ signature, we selected 4 types of forest with different types of vegetation. In one forest area (CB), the vegetation switched from conifer (C) to broadleaved (B) forest in 1954 after a typhoon. In another forest (BC), broadleaved forest was replaced by a conifer plantation in 1963. Two control forests were $\mathrm{CC}$ (continuous conifer) and $\mathrm{BB}$ (continuous broadleaved). The $\mathrm{BB}$ and $\mathrm{CB}$ sites were within a deciduous stand dominated by Japanese oak (Quercus crispula) with some Japanese elm 
(Ulmus davidiana), Japanese white bark magnolia (Magnolia obovata), and Prunus ssiori. Conifer stands were dominated by Pinaceae, Picea jezoensis in CC, and Abies sachalinensis in BC. Both conifer stands contained some Japanese oak (Q. crispula), Matsumurae maple (Acer amoenum), Japanese white bark magnolia ( $M$. obovata), and Japanese lime (Tilia japonica). The stand basal area was estimated by measuring the diameter of trees $(\mathrm{DBH}>5 \mathrm{~cm})$ at chest height $(1.3 \mathrm{~m})$ in a $50 \times 50 \mathrm{~m}$ plot at each site. The diameter of small trees with $\mathrm{DBH}<5 \mathrm{~cm}$ was not recorded.

\section{Sample Collection and Preparation}

Five litter traps (open area $0.5 \mathrm{~m}^{2}$ ) were set at each site to measure litter production and ${ }^{14} \mathrm{C}$ values. The litter fallen into the traps was collected monthly from May to November 2007, oven-dried at $60{ }^{\circ} \mathrm{C}$ overnight, and weighed. Other sampling was carried out in October 2007. To estimate the mass of litter accumulation on the forest floor, 5 replicates of $O$ layer samples (quadrate samples) were collected from each $25 \times 25 \mathrm{~cm}$ quadrate. Samples were oven dried at $60^{\circ} \mathrm{C}$ overnight and weighed. At the same location, soil macroinvertebrates $(>2 \mathrm{~mm})$ were collected by hand sorting within these $\mathrm{O}$ layers $(25 \times 25 \mathrm{~cm}$ quadrate, 5 replicates $)$ and soil down to the deepest layer in the A horizon below these O layers. Soil fauna individuals in the Haplotaxida and Isopoda orders were identified at species level according to Easton (1981), Ishizuka (2001), and Blakemore (2003), those in the Diplopoda and Coleoptera (adults) were identified at family level, and other animals were identified at order level. The biomass of individual fauna was measured. Earthworm specimens were collected from quadrates and from surrounding areas to obtain sufficient samples for isotope analysis. For isotope analyses, soil macroinvertebrates were kept in glass containers with distilled water at $15^{\circ} \mathrm{C}$, allowing them to empty their gut contents. After $36-48 \mathrm{hr}$, they were rinsed with distilled water to remove soil and feces, and freeze-dried for $48 \mathrm{hr}$. Each specimen was ground to a fine powder using an agate mortar and pestle, and its isotope ratio was measured individually. At the BB site, casts of earthworms (Megascolecidae) were collected because there were large amounts of visible casts in the soil surface layer down to $4 \mathrm{~cm}$ depth.

A 50-cm-long, open iron cylinder with a diameter of $110 \mathrm{~mm}$ (core sampler) was used to obtain a core from the surface $\mathrm{O}$ layer to the deepest layer of soil (A layer). We extracted 3 cylinder-shaped cores (16 or $18 \mathrm{~cm}$ deep) from the $\mathrm{O}$ layer and $\mathrm{A}$ layer above the volcanic ash layer in 1739 at each of the 4 sites (BC, CB, BB, and CC). The depth of these cores, i.e. the depth until the 1739 volcanic ash layer, was $16 \mathrm{~cm}$ in $\mathrm{BC}, \mathrm{CB}$, and $\mathrm{BB}$, and $18 \mathrm{~cm}$ in $\mathrm{CC}$. Each core was divided in 2-cm fragments along its depth for analyses, and the thickness of its $\mathrm{O}$ layer was measured. The samples were dried at $60{ }^{\circ} \mathrm{C}$ for $48 \mathrm{hr}$, then gravel, coarse litter, and roots were removed using a sieve $(9.5-\mathrm{mm}$ mesh size), and the sample was weighed. We analyzed the sample for ${ }^{14} \mathrm{C}$ content, stable isotope ratios, and organic carbon content. Because we intended to include earthworm casts (often as large as several millimeters) into examined soils for analysis of carbon and isotopes, a 9.5-mm mesh size was used for the preparation of the samples. Carbon content and stable isotope ratios were measured at each depth in each core (3 replicates). For ${ }^{14} \mathrm{C}$ analysis, however, we combined 3 samples at each depth from 3 separate cores at each site into 1 composite sample. The ${ }^{14} \mathrm{C}$ concentration in the $\mathrm{O}$ layer was measured in composite samples made from $\mathrm{O}$ layer (quadrates) samples from 5 replicates at each site, independently of the core samples. Each sample was treated with $0.5 \mathrm{M} \mathrm{HCl}$ to remove carbonate, then washed with distilled water and dried.

\section{Analyses}

Organic carbon and nitrogen concentrations in the $\mathrm{O}$ layer, soils, and litter fall were analyzed using an NC analyzer (SUMIGRAPH NC-95A, SHIMADZU, Kyoto, Japan). Carbon $\left(\delta^{13} \mathrm{C}\right)$ and nitrogen $\left(\delta^{15} \mathrm{~N}\right)$ isotope ratios in soil invertebrates, earthworm casts, $\mathrm{O}$ layers, soils at each depth, and litter 
fall were measured using the following procedure. The samples were enclosed in tin capsules and analyzed by an elemental analyzer (EA1108, Fisons, Italy) connected to an isotope ratio mass spectrometer (Delta S, Finnigan MAT ${ }^{\mathrm{TM}}$, Bremen, Germany). The precision of the on-line procedure was better than $\pm 0.2 \%$ for both isotope ratios. The natural abundances of ${ }^{13} \mathrm{C}$ and ${ }^{15} \mathrm{~N}$ are expressed in per mil (\%) deviation from international standards; $\delta^{13} \mathrm{C}$ or $\delta^{15} \mathrm{~N}=\left(R_{\text {sample }} / R_{\text {standard }}-1\right) \times 1000$, where $R$ in $\delta^{13} \mathrm{C}$ and $\delta^{15} \mathrm{~N}$ is ${ }^{13} \mathrm{C} /{ }^{12} \mathrm{C}$ and ${ }^{15} \mathrm{~N} /{ }^{14} \mathrm{~N}$, respectively. Pee Dee Belemnite and atmospheric nitrogen are the international standards for carbon and nitrogen, respectively.

For ${ }^{14} \mathrm{C}$ analysis, samples (estimated to produce about $1.5 \mathrm{mg}$ of carbon) were combusted in evacuated and sealed $\mathrm{Vycor}^{\circledR}$ tubes with $\mathrm{CuO}, \mathrm{Cu}$, and $\mathrm{Ag}$ wire at $850^{\circ} \mathrm{C}$ for $2 \mathrm{hr}$. After cooling, the Vycor tubes were cracked on a vacuum line, and the $\mathrm{CO}_{2}$ was cryogenically purified. The purified $\mathrm{CO}_{2}$ was graphitized under $\mathrm{Fe}$ catalysis at $650{ }^{\circ} \mathrm{C}$ for $6 \mathrm{hr}$ (Kitagawa et al. 1993). The concentration of ${ }^{14} \mathrm{C}$ was measured by accelerator mass spectrometry (AMS) following the method of Uchida et al. (2004a) in NIES-TERRA, Japan, or by AMS in the Rafter Radiocarbon Laboratory, Institute of Geological and Nuclear Sciences, New Zealand. The ${ }^{14} \mathrm{C}$ concentrations are reported as ${ }^{14} \mathrm{C}$ values, as defined by Stuiver and Polach (1977). Positive ${ }^{14} \mathrm{C}$ values indicate the presence of bomb-induced ${ }^{14} \mathrm{C}$, and negative values indicate the predominance of SOM with ${ }^{14} \mathrm{C}$ that has experienced significant radioactive decay (half-life $5730 \mathrm{yr}$ ).

\section{Carbon Ages in Litter and Earthworms}

In this paper, we define "carbon age" as the time that has elapsed since carbon (C) was fixed from atmospheric $\mathrm{CO}_{2}$ by primary producers. The carbon age of soil animals is identical to the "diet age" defined by Hyodo et al. (2006). We expand this definition to organic matter, including litter and earthworm casts. Carbon ages were estimated by comparing the ${ }^{14} \mathrm{C}$ content of samples with records of atmospheric ${ }^{14} \mathrm{CO}_{2}$, which doubled in the early 1960s and is still decreasing after the Nuclear Test Ban Treaty. We determined the carbon ages of litter fall, $\mathrm{O}$ layers, and earthworms from the difference between the sample collection year (2007) and the year $(\mathrm{t})$ when the ${ }^{14} \mathrm{C}$ value of the sample matched that of atmospheric $\mathrm{CO}_{2}$. We used the data of atmospheric ${ }^{14} \mathrm{CO}_{2}$ for the Northern Hemisphere (Levin and Kromer 2004; Levin et al. 2008). The year ( $\mathrm{t}$ ) was calculated using a regression curve as follows: year $(\mathrm{t})=2073.9-16.71 \ln \left({ }^{14} \mathrm{C}\right)\left(r^{2}=0.997, P<0.0001\right)($ Hua and Barbetti 2004), following Hyodo et al. (2008). ${ }^{14} \mathrm{C}$ measurements of soil animals and their food resources (litter, O layer, and soil) provide important information about what fraction of organic matter the soil animals have consumed and how long the organic matter was retained in the soil. As the O layer and SOM are "unconsumed" fractions, the "consumed" fraction can be estimated only by analyzing animals that consumed (assimilated) the fraction.

\section{Statistical Analyses}

We hypothesized that vegetation types affect the abundance of soil invertebrates, resulting in changes in the soil carbon accumulation pattern. To test this hypothesis, data on litter, soils, invertebrates, and carbon ages of earthworms were tested by one-way ANOVA with vegetation types (CC, $\mathrm{CB}, \mathrm{BB}$, and $\mathrm{BC}$ ) as the main factor. Differences among sites in $\mathrm{O}$ layer accumulation, soil $\mathrm{C}$ stock, and the biomass of soil invertebrates were assessed by one-way ANOVA, followed by TukeyKramer multiple comparison tests. Simple regression analysis was used to assess the effect of carbon ages on $\delta^{15} \mathrm{~N}$ values of the earthworms at each site. All analyses were performed using R environment v 2.8.0 for statistical computing (R Development Core Team 2006). 


\section{RESULTS}

\section{Litter Production and Carbon Stock at the Forest Floor}

The amount of litter fall in the 4 forest types ranged from 0.17 to 0.29 dry $\mathrm{kg} / \mathrm{m}^{2}$ (Table 1). The total $\mathrm{O}$ layer carbon stock was significantly lower in current broadleaved forests (BB and $\mathrm{CB}$ ) than in current coniferous forests $(\mathrm{CC}$ and $\mathrm{BC})$ (Tukey-Kramer-test, $P<0.05)$. Total soil carbon did not differ significantly among the 4 sites (one-way ANOVA, $F_{3,8}=1.84, P=0.22$ ). The total stem basal area varied from $13.69 \mathrm{~cm}^{2} / \mathrm{m}^{2}(\mathrm{CB})$ to $37.59 \mathrm{~cm}^{2} / \mathrm{m}^{2}(\mathrm{BC})$.

Table 1 Stem basal area (BA), litter fall above ground, and total carbon in O layer and soil below ground ( $n=5$ in O layer; $n=3$ in soil; mean \pm S.D.) in each site.

\begin{tabular}{cllll}
\hline Site & $\begin{array}{l}\text { BA } \\
\left(\mathrm{cm}^{2} / \mathrm{m}^{2}\right)\end{array}$ & $\begin{array}{l}\text { Litter fall } \\
\left(\mathrm{kg} / \mathrm{m}^{2} / \mathrm{yr}\right)\end{array}$ & $\begin{array}{l}\text { O layer C } \\
\left(\mathrm{kg} / \mathrm{m}^{2}\right)\end{array}$ & $\begin{array}{l}\text { Soil C } \\
\left(\mathrm{kg} / \mathrm{m}^{2}\right)\end{array}$ \\
\hline $\mathrm{CC}$ & 35.36 & 0.24 & $1.9 \pm 0.77^{\mathrm{b}}$ & $4.3 \pm 1.34^{\mathrm{a}}$ \\
$\mathrm{BB}$ & 22.99 & 0.25 & $0.4 \pm 0.15^{\mathrm{a}}$ & $3.2 \pm 0.14^{\mathrm{a}}$ \\
$\mathrm{CB}$ & 13.69 & 0.17 & $0.3 \pm 0.09^{\mathrm{a}}$ & $3.4 \pm 0.28^{\mathrm{a}}$ \\
$\mathrm{BC}$ & 37.59 & 0.29 & $1.5 \pm 0.28^{\mathrm{b}}$ & $3.0 \pm 0.29^{\mathrm{a}}$ \\
\hline
\end{tabular}

\section{Depth Distribution of SOM and ${ }^{14} \mathrm{C}$}

$\Delta^{14} \mathrm{C}$ values were in the range of $5-160 \%, 73-134 \%$, $48-118 \%$, and $48-112 \%$ for $\mathrm{CC}, \mathrm{BB}, \mathrm{CB}$, and $\mathrm{BC}$, respectively (Figure 1). $\Delta^{14} \mathrm{C}$ values in $\mathrm{BB}, \mathrm{CB}$, and $\mathrm{BC}$ were relatively high at all depths. In $\mathrm{CC}$, however, $\Delta^{14} \mathrm{C}$ values of $<10 \%$ were found in the deeper layers $(12-14,14-16 \mathrm{~cm})$. These values indicate a higher amount of "pre-bomb" organic matter. The O layer (in cylinders) had an average thickness of $4.5,1.5,2$, and $3 \mathrm{~cm}$ in $\mathrm{CC}, \mathrm{BB}, \mathrm{CB}$, and $\mathrm{BC}$, respectively. Carbon concentration was $>30 \%$ until $4 \mathrm{~cm}$ depth in $\mathrm{CC}$, and $2 \mathrm{~cm}$ depth in $\mathrm{CB}$ and $\mathrm{BC}$, whereas it was $<30 \%$ even in the top $0-2 \mathrm{~cm}$ depth in $\mathrm{BB}$. The depths of layers in which carbon concentration was greater than $20 \%$ corresponded with the thickness of O layers (in cylinders) in CC, BB, and CB. The O layer (determined from composite quadrate samples) had $\Delta^{14} \mathrm{C}$ values of $84 \%$, $81 \%$, $66 \%$, and $91 \%$ in $\mathrm{CC}, \mathrm{BB}, \mathrm{CB}$, and $\mathrm{BC}$, respectively.

\section{Soil Fauna Composition}

Total biomass of invertebrates differed significantly among the sites (one-way ANOVA, $F_{3,16}=$ $7.53, P=0.002)$. The total biomass was significantly higher in the current broadleaved forests (BB, $14.1 \mathrm{~g} \mathrm{dry} / \mathrm{m}^{2}$ and $\mathrm{CB}, 12.8 \mathrm{~g}$ dry $\left./ \mathrm{m}^{2}\right)$ than in the current coniferous forests $\left(\mathrm{CC}, 3.6 \mathrm{~g} \mathrm{dry} / \mathrm{m}^{2}\right.$ and $\mathrm{BC}, 2.1 \mathrm{~g} \mathrm{dry} / \mathrm{m}^{2}$; Tukey-Kramer test, $P<0.05$ ). Large Oligochaeta (earthworms) were dominant soil macroinvertebrates at all sites (Table 2). The earthworm species collected comprised Megascolecidae (Metaphire hilgendorfi, Amynthas yunoshimaensis, and Amynthas vittatus) and Lumbricidae (Eisenia japonica). Apart from in BC, Megascolecidae earthworms were dominant, especially $M$. hilgendorfi, which had the highest biomass in $\mathrm{BB}$ and $\mathrm{CB}$. However, M. hilgendorfi was not found in either of the current coniferous forest sites (CC and $\mathrm{BC}$ ). The biomass of litter-feeding soil invertebrates (Megascolecidae earthworms; M. hilgendorfi, A. yunoshimaensis, and A. vittatus, Isopoda; Ligidium japonicum, Diplopoda) was significantly higher in the current broadleaved forests (BB, $12.8 \mathrm{~g}$ dry $/ \mathrm{m}^{2} ; \mathrm{CB}, 10.6 \mathrm{~g}$ dry $/ \mathrm{m}^{2}$ ) than in the current coniferous forests (CC, $2.8 \mathrm{~g} \mathrm{dry} / \mathrm{m}^{2} ; \mathrm{BC}, 2.0$ $\mathrm{g}$ dry $/ \mathrm{m}^{2}$; Tukey-Kramer test, $\left.P<0.05\right)$. In contrast, the biomass of the Lumbricidae earthworm Eis- 


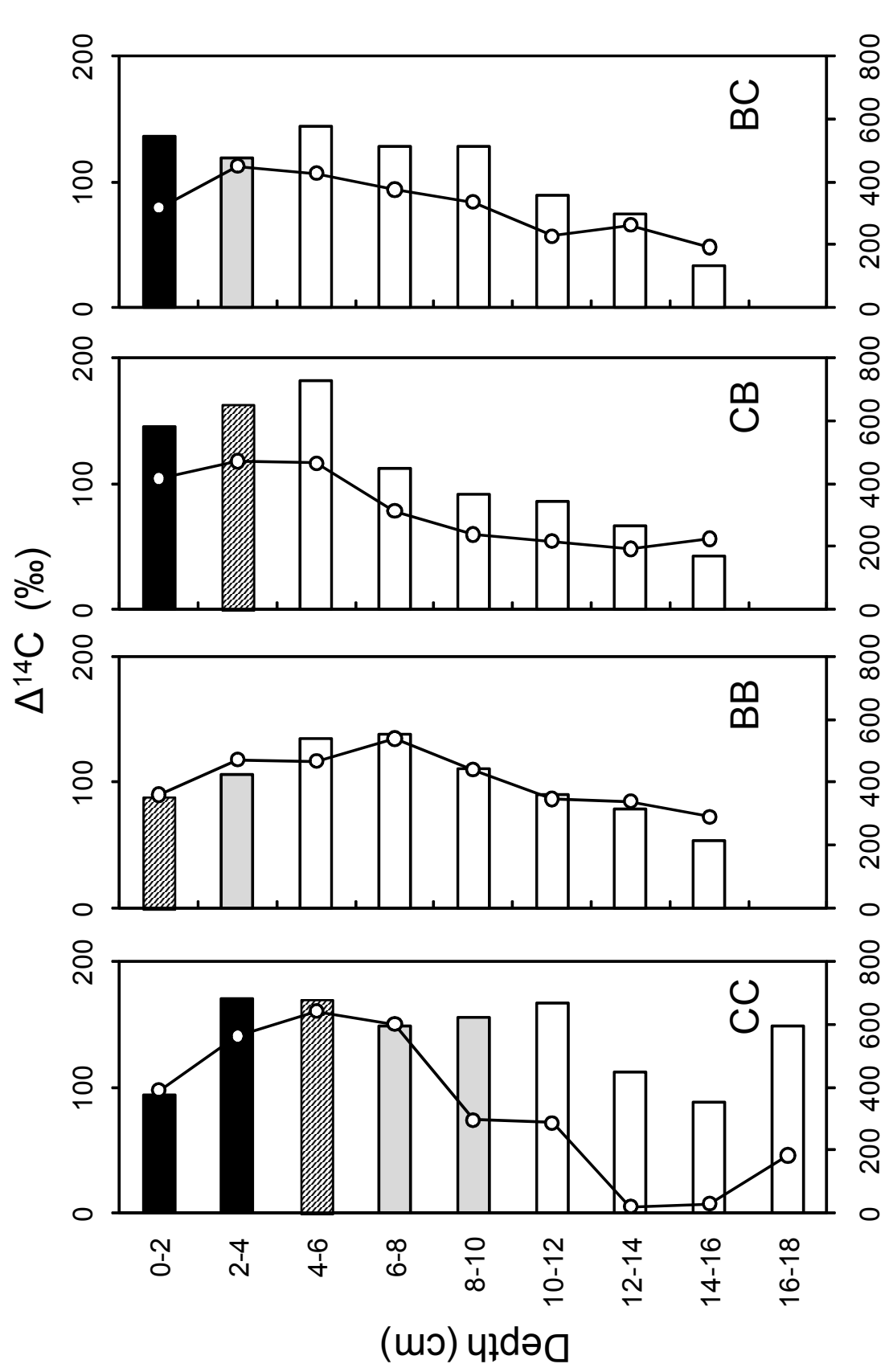

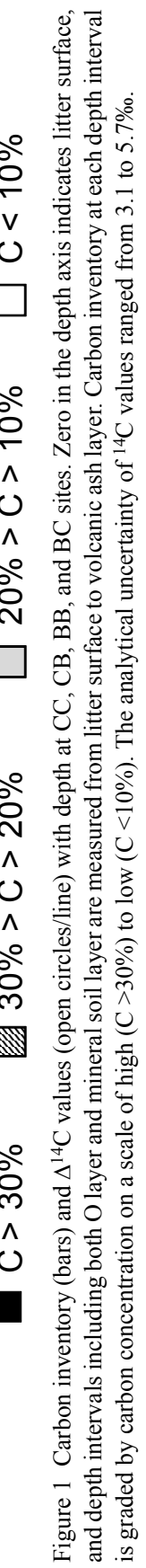


enia japonica (Lumbricidae), which is categorized as a soil feeder, was not significantly different among sites (one-way ANOVA, $F_{3,16}=0.81, P=0.51$ ).

\section{$\delta^{15} \mathrm{~N}$ and $\delta^{13} \mathrm{C}$ of Organic Matter and Soil Animals}

Overall, the data set showed that the $\delta^{15} \mathrm{~N}$ and $\delta^{13} \mathrm{C}$ values ranged from -4.7 to $+5.4 \%$ and -30.8 to $-22.3 \%$, respectively (Figure 2). On the basis of combined $\delta^{15} \mathrm{~N}$ and $\delta^{13} \mathrm{C}$ values, 3 ecological categories of animals were established: litter-feeding invertebrates (Megascolecidae and Isopoda, $L$. japonicum), soil-feeding earthworms (Lumbricidae, E. japonica), and predators (Araneae, Carabidae, and Chilopoda). Litter-feeding invertebrates had lower $\delta^{15} \mathrm{~N}$ values than soil-feeding earthworms and predators (Figure 2). The soil-feeding earthworm E. japonica had $\delta^{15} \mathrm{~N}$ values similar to those of the invertebrates that were categorized as predators in $\mathrm{CC}$ and $\mathrm{BB}$, respectively. In contrast to $\mathrm{CC}$ and $\mathrm{BB}$, E. japonica in $\mathrm{BC}$ had slightly higher $\delta^{13} \mathrm{C}$ and $\delta^{15} \mathrm{~N}$ values than the litter-feeding earthworms. M. hilgendorfi in $\mathrm{CB}$ tended to have higher $\delta^{13} \mathrm{C}$ and $\delta^{15} \mathrm{~N}$ values than the other litterfeeders. Stable isotope ratios of E. japonica in CB could not be measured because of their low biomass (Table 2).

\section{Carbon Age of Litter and Earthworms}

The differences between the carbon age of litter fall and that of the $\mathrm{O}$ layer (quadrate samples) were consistent among the sites (Figure 3 ). $\delta^{15} \mathrm{~N}$ values of earthworms significantly increased with carbon age in $\mathrm{CC}(P<0.01)$ and $\mathrm{BC}(P<0.05)$, where E. japonica (Lumbricidae) assimilated older carbon (CC, 10-15 yr old, BC, 5-15 yr old) than the litter-feeding (Megascolecidae) earthworms did (Figure 3). In BB, the carbon age of litter-feeding earthworms (Megascolecidae) was similar to that of a soilfeeding E. japonica earthworm (around $10 \mathrm{yr}$ ), however their $\delta^{15} \mathrm{~N}$ values varied widely. In CB, carbon ages of the earthworm $M$. hilgendorfi varied widely ( $>15 \mathrm{yr}$ at the maximum), while its $\delta^{15} \mathrm{~N}$ values were very similar.

\section{DISCUSSION}

\section{Effects of Litter Types and Animal Communities on SOC Accumulation in Continuous Forests}

Previous studies have reported that biological mixing by soil macroinvertebrates, known as "bioturbation" (Scheu 1987), homogenizes the ${ }^{14} \mathrm{C}$ concentration in soils by comparing the ${ }^{14} \mathrm{C}$ data of soils in the presence or absence of earthworms (Stout and Goh 1980). In the case of the TOEF depth intervals, if there were no bioturbation, the vertical profile of $\Delta{ }^{14} \mathrm{C}$ values should have been higher in surface layers, maximizing in the layer of $1960 \mathrm{~s}$, and decreasing to almost zero at the bottom because the SOC had accumulated for $268 \mathrm{yr}$ after the eruption of Mt. Tarumae in 1739 . The $\Delta^{14} \mathrm{C}$ values at depth intervals in CC showed good agreement with the expected profile, and the profile was consistent with those reported previously for forest soils (Trumbore 2000). Low $\Delta^{14} \mathrm{C}$ values $(<10 \%$ ) in the deeper 2 layers $(12-14$ and $14-16 \mathrm{~cm}$ ) in CC indicate that the post-bomb signal (at least higher than $50 \%$ ) has contributed little to these layers because the oldest carbon in the soil had $\Delta^{14} \mathrm{C}$ values around zero (theoretically in 1739: before the Suess effect). However, the deepest soil layer analyzed $(16-18 \mathrm{~cm})$ in $\mathrm{CC}$ had a higher $\Delta^{14} \mathrm{C}$ value $(\sim 50 \%)$ and carbon concentration $(5.4 \%)$ than the upper 2 layers (12-14 and 14-16 cm). This indicates that the post-bomb signal has contributed little to the 2 deeper layers $(12-14$ and $14-16 \mathrm{~cm})$ and the carbon input at the deepest layer $(16-18 \mathrm{~cm})$ cannot be explained without considering the contribution of root carbon. Although plant roots are thought to increase $\Delta^{14} \mathrm{C}$ values in soils, few studies have demonstrated their effects. In this study, we detected the effects of plant roots on the $\Delta^{14} \mathrm{C}$ pattern because the accumulated carbon was less than 268 yr old and older carbon does not exist. However, at the other sites (BC, CB, and BB), carbon input to SOC by root production cannot be distinguished from carbon input by litter fall. 


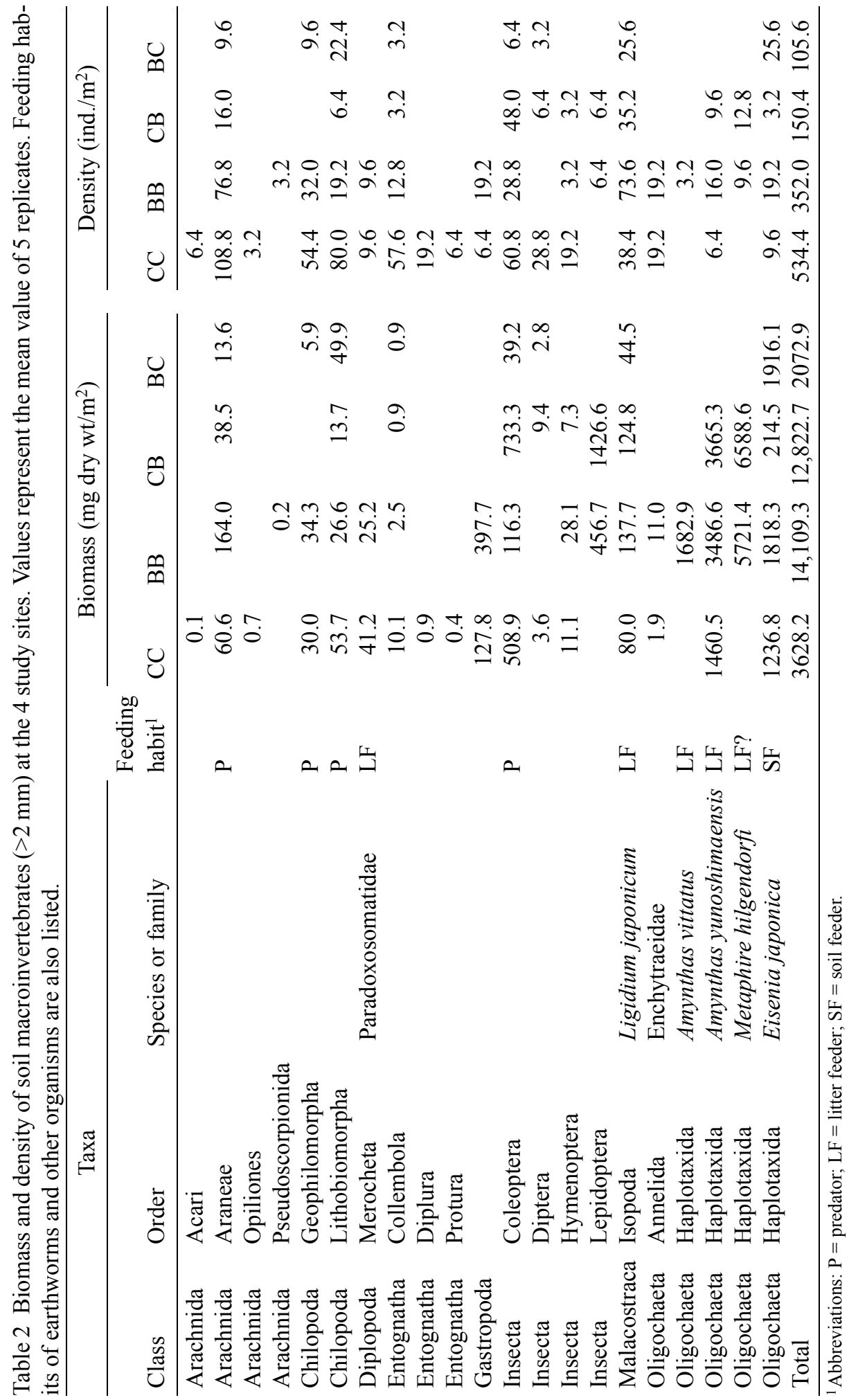




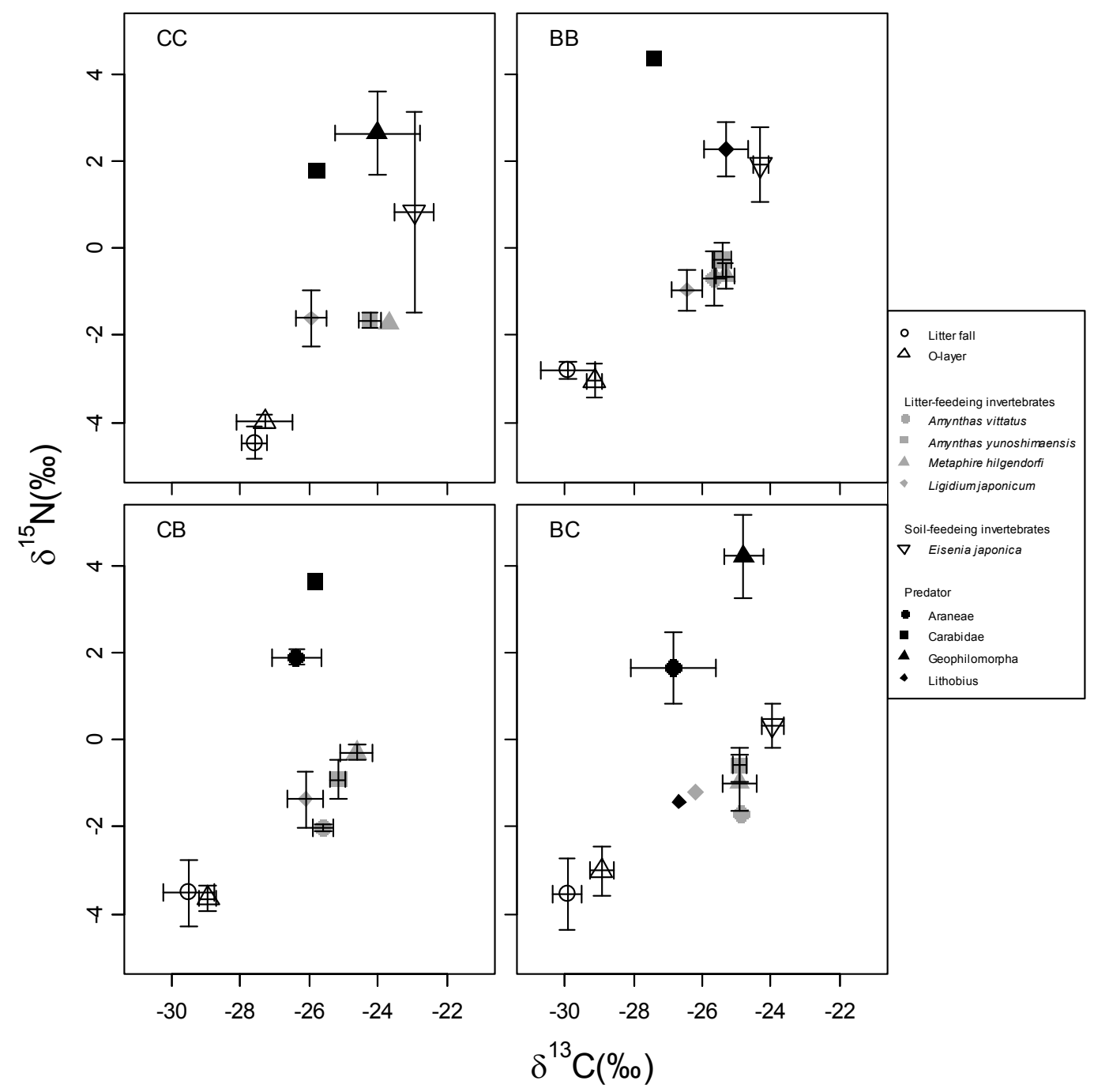

Figure 2 Carbon and nitrogen stable isotope ratios of soil invertebrates and their food sources (litter fall and O layer; quadrate samples). Symbols indicate average value of replicates ( $n=2$ to 12$)$ of each individual species or taxon. Error bars represent standard deviation (error bars not shown when $n=2$ ).

In contrast, $\Delta{ }^{14} \mathrm{C}$ values of $\mathrm{BB}$ showed relatively high ${ }^{14} \mathrm{C}$ concentrations even in the deepest soil layer, which strongly suggests that the bomb-induced ${ }^{14} \mathrm{C}$ has been mixed by soil invertebrates. The biomass of earthworms (litter- and soil-feeding forms) and litter-feeding invertebrates was higher in BB than in CC (Table 2). Bioturbation has been reported for endogeic earthworms in general (e.g. Scheu 1987), because litter-feeding earthworms mainly inhabit the litter and surface soil layers (Edwards 1998). However, the biomass and density of the endogeic earthworm E. japonica were similar between CC and BB (Table 2). The $\delta^{13} \mathrm{C}$ and $\delta^{15} \mathrm{~N}$ values of litter-feeding earthworms were markedly lower than those of soil feeders. This result is consistent with many previous reports (e.g. Schmidt et al. 2004). In this study, M. hilgendorfi, A. yunoshimaensis, and A. vittatus were categorized as litter-feeders (epigeic species), whereas E. japonica was categorized as a soil-feeder (endogeic species) based on their $\delta^{13} \mathrm{C}$ and $\delta^{15} \mathrm{~N}$ values (Figure 2). These results are consistent with 


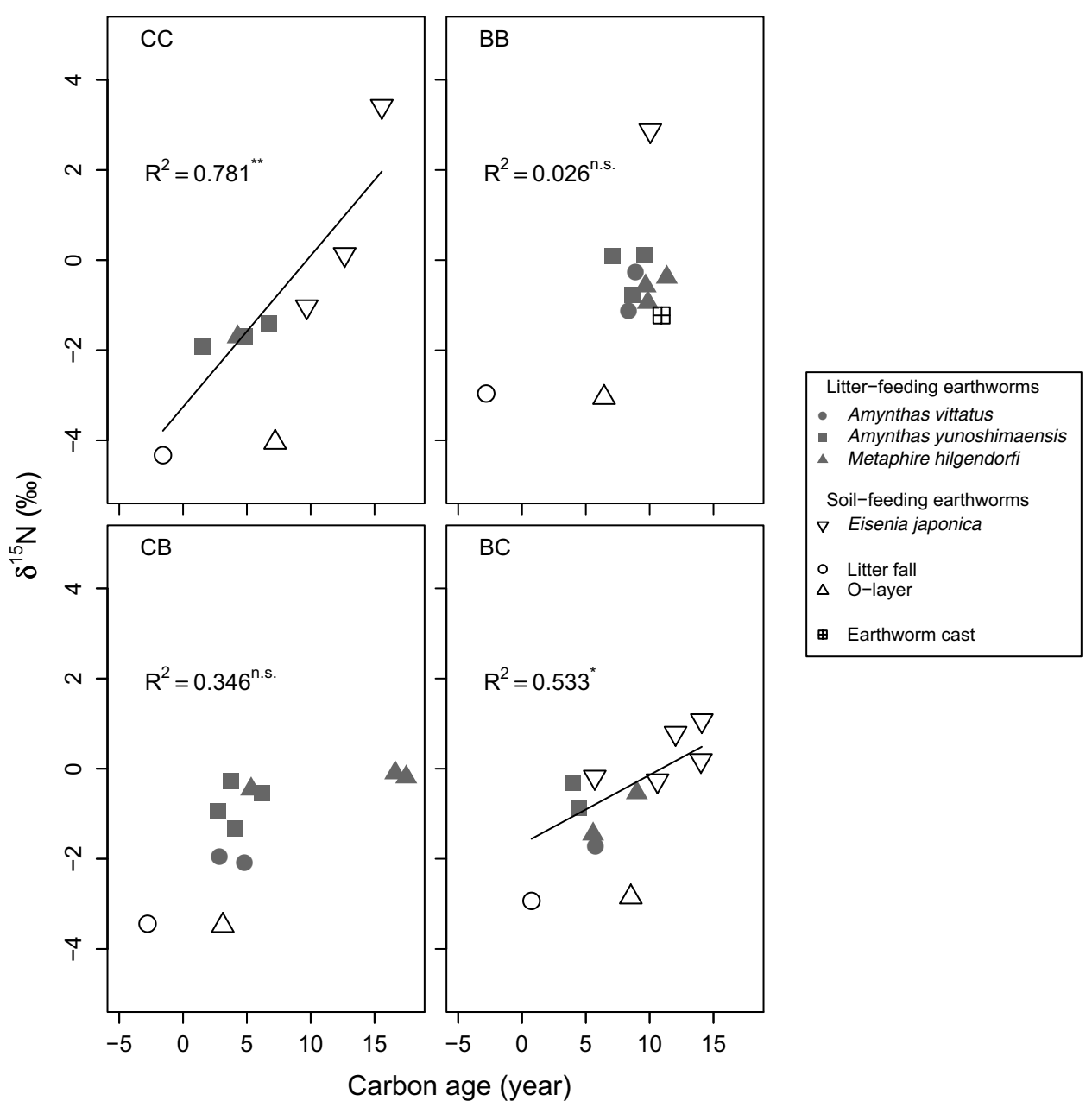

Figure 3 Relationship between carbon ages calculated from $\Delta{ }^{14} \mathrm{C}$ values (see text) and nitrogen stable isotope ratios of earthworms, cast, litter fall, and O layer (quadrate samples). Solid lines represent significant relationships in earthworms. Coefficients of determination and significance levels $(* P<0.05, * * P<0.01$, ns $=$ not significant $)$ are shown. Analytical uncertainty of carbon ages ranged from 0.4 to $1.5 \mathrm{yr}$ (equivalent to 2.8 to $6.0 \%$ in $\Delta{ }^{14} \mathrm{C}$ ).

those reported previously for M. hilgendorfi, A. vittatus, and E. japonica at this study site (Uchida et al. 2004b). On the other hand, Uchida et al. (2004b) reported that in broadleaved forests in the TOEF, the gut contents of the litter-feeding earthworm M. hilgendorfi contained $>30 \%$ inorganic materials. Therefore, these earthworms are not restricted to the $\mathrm{O}$ layer but burrow into soil layers. In this way, they may transfer carbon from litter to soil by digesting leaf litter and producing casts in broadleaved forests. Thus, the reason why $\Delta^{14} \mathrm{C}$ profiles were not mixed in $\mathrm{CC}$ may have been because of a lack of the litter-feeding earthworm M. hilgendorfi (Table 2). In addition, Bonkowski et al. (1998) reported that under microcosm experimental conditions, the growth of soil-feeding earthworms increased when litter-feeding millipedes were also present. They suggested that litter consumption by litter-feeding invertebrates, such as earthworms and millipedes, provides food resources for soil-feeding earthworms. In our results, the carbon age of fresh casts of litter-feeding earthworms in BB was similar to that of the soil-feeding earthworm E. japonica, and the $\delta^{15} \mathrm{~N}$ value of E. japonica was $\sim 4 \%$ higher than that of the casts (Figure 3 ). These results suggest that the soil- 
feeding earthworm E. japonica assimilated the casts of litter-feeding earthworms in broadleaved forest. The coexistence of litter-feeding invertebrates and soil-feeding earthworms may accelerate vertical mixing of recent SOC into deeper soil layers.

Although the amount of litter fall was similar in $\mathrm{BB}$ and $\mathrm{CC}$, less carbon accumulated in the $\mathrm{O}$ layer of $\mathrm{BB}$ than in the $\mathrm{O}$ layer of $\mathrm{CC}$ (Table 1). These results supported the hypothesis that more carbon is supplied from the $\mathrm{O}$ layer to soil in $\mathrm{BB}$ than in $\mathrm{CC}$. This is consistent with the general pattern that the carbon stock in $\mathrm{O}$ layers of coniferous forests is greater than that in $\mathrm{O}$ layers of broadleaved forests in cool temperate regions (Cole and Rapp 1981). Using a litter-bag technique in which earthworms were excluded, Miyamoto and Hiura (2008) demonstrated that oak leaf litter was lost significantly faster than the fir needle litter in the $\mathrm{O}$ layer in this region. Their results also indicated that litter types were responsible for $\mathrm{O}$ layer accumulation patterns. On the other hand, litter loss in the O layer depends not only on litter types, but also on soil invertebrate activities in the temperate zone (Wall et al. 2008). In the TOEF broadleaved forest, experimental removal of litter-feeding earthworms decreased the disappearance of the $\mathrm{O}$ layer. Furthermore, soil carbon accumulation in the treatment without earthworms was lower than that in the treatment with earthworms, because a large proportion of litter consumed by litter-feeding earthworms is not assimilated (Kawaguchi et al., unpublished results). The global distribution pattern of soil animals shows that the abundance of soil animals in the temperate deciduous forests is higher than that in the temperate coniferous forests (Petersen and Luxton 1982; Fierer et al. 2009). In this study, the biomass of litter-feeding invertebrates in $\mathrm{BB}$ was also higher than that in $\mathrm{CC}$. In addition, the biomass of earthworms was large in broadleaved forests (BB), in fact, twice as high as the average biomass in temperate deciduous forests (Petersen and Luxton 1982). The high biomass of earthworms would have a considerable effect on the reduction of $\mathrm{O}$ layer mass and the supply of carbon from litter to soil in broadleaved forests.

\section{Effects of Changes in Litter Types and Animal Communities on SOC Accumulation in Vegetation-Switched Forests}

In the vegetation-switched sites $(\mathrm{CB}$ and $\mathrm{BC})$, the bomb- ${ }^{14} \mathrm{C}$ peak was less prominent than that in CC (Figure 1). The differences in soil fauna (Table 2), especially the significant difference of litterfeeding invertebrates between current coniferous (CC and $\mathrm{BC}$ ) and broadleaved forests (BB and $\mathrm{CB}$ ), suggest that the vegetation switch resulted in changes in the soil animal community. As population dynamics of litter-feeding invertebrates are sensitive to litter quality (Loranger-Merciris et al. 2008), the absence of litter-feeding earthworms in BC would have been caused by the vegetation switch from broadleaved forest to coniferous forest. The amount of carbon accumulation in O layers was also explained by current vegetation type even in vegetation-switched sites (Table 1). The mass of the $\mathrm{O}$ layer was greater in $\mathrm{BC}$ than in $\mathrm{CB}$; this would have resulted from the low decomposition rate of recent needle litter and the low biomass of litter-feeding invertebrates in $\mathrm{BC}$. In contrast, the $\Delta^{14} \mathrm{C}$ values were high across all depth intervals (minimum $\Delta^{14} \mathrm{C}$ is $48 \%$ ) in $\mathrm{BC}$, indicating the occurrence of bioturbation. This appears to contradict the lower biomass of litter-feeding invertebrates in $\mathrm{BC}$ than that in the current broadleaved forest (CB and BB). However, it is probable that the biomass of litter-feeding invertebrates in BC may have been higher in 1963 when the vegetation was broadleaved species, before conversion to coniferous forest. The litter-feeding invertebrates such as the earthworm $M$. hilgendorfi may have mixed the bomb ${ }^{14} \mathrm{C}$ in soil under the broadleaved forest in the early 1960 s when bomb ${ }^{14} \mathrm{C}$ was being produced.

In contrast to $\mathrm{BC}$, earthworm biomass in $\mathrm{CB}$ was 4 times higher than in $\mathrm{CC}$. The result suggested that the soil layers of $\mathrm{CB}$ could have been mixed by earthworms after the vegetation switch, because M. hilgendorfi, which is a potential soil mixer, dominated in CB. The difference in $\Delta^{14} \mathrm{C}$ distribution in depth between $\mathrm{CB}$ and $\mathrm{CC}$ indicated that the vegetation change from coniferous forest to broad- 
leaved forest had greatly modified the SOC accumulation patterns after the vegetation switch. In contrast, the similar patterns of $\Delta^{14} \mathrm{C}$ values between $\mathrm{BB}$ and $\mathrm{BC}$ suggested that the vegetation change from broadleaved forest to coniferous forest in $\mathrm{BC}$ had little influence on their $\Delta^{14} \mathrm{C}$ patterns. These results suggest that the presence of broadleaved forest, whether past or present, is an important factor in the distribution of $\Delta^{14} \mathrm{C}$ across soil depth. It is still unclear whether or not changes in litter type after a vegetation switch lead to changes in SOC accumulation rate. Our results indicate that the abundant soil invertebrates disturbed the SOC accumulation pattern in broadleaved forests. Therefore, future studies should consider the roles of soil fauna in SOC dynamics, and should analyze the effects of soil invertebrates and litter type separately.

\section{Roles of Invertebrates in SOC Accumulation Patterns}

All of the examined earthworms showed carbon ages of $<20$ yr (Figure 3). Because the vegetation switches occurred in 1954 and 1963 at the CB and BC sites, respectively, this result implies that earthworms assimilated the dietary matter derived from the current vegetation litter. Therefore, the earthworms are closely related to the current vegetation type. There was a significant correlation between the carbon ages and $\delta^{15} \mathrm{~N}$ values in earthworm bodies in the current coniferous forests (CC and BC) (Figure 3). In particular, E. japonica showed higher values of carbon ages and $\delta^{15} \mathrm{~N}$ compared with those of other earthworms. The isotopic ratio of the body reflects characteristics of the dietary materials assimilated by the animals. Because $\delta^{15} \mathrm{~N}$ values increase with humification of organic matter in soils (Tayasu et al. 1997), higher values of $\delta^{15} \mathrm{~N}$ of E. japonica indicate that they utilized and assimilated highly decayed organic materials. On the other hand, the low values of diet ages and $\delta^{15} \mathrm{~N}$ in the other earthworms with litter-feeding habits suggest that they assimilated relatively "fresh" organic matter in $\mathrm{CC}$ and $\mathrm{BC}$. Therefore, we concluded that the positive correlation between carbon ages and $\delta^{15} \mathrm{~N}$ in the current coniferous forests probably resulted from humification process of dietary materials, i.e. the decomposition of SOM over time.

A similar trend was reported by Hyodo et al. (2008), who reported on the relationship among termites and earthworms in the tropics (Ivory Coast). This is the first report of a positive relationship between carbon age and $\delta^{15} \mathrm{~N}$ values of soil animals in a cool temperate forest. In contrast to CC and $\mathrm{BC}$, there was no significant correlation between carbon age and $\delta^{15} \mathrm{~N}$ in the current broadleaved forests ( $\mathrm{BB}$ and $\mathrm{CB}$ ). The reason is unclear, however; the relationships were dependent on current vegetation types. The carbon ages of $M$. hilgendorfi in $\mathrm{CB}$ varied widely, ranging from 5 to $17 \mathrm{yr}$, although the $\delta^{15} \mathrm{~N}$ values were almost constant (Figure 3). Carbon ages of the other litter-feeding earthworms were similar to those of the O layers (Figure 3). Neilson et al. (2000) showed that stable isotope ratios of epigeic (litter-feeding) earthworms were different from endogeic (soil-feeding) earthworms, although anecic (deep-burrowing) earthworms were rather site-dependent. Thus, it is probable that $M$. hilgendorf in $\mathrm{CB}$ is an intermediate group between epigeic and anecic forms. Further studies are required to determine the generality of the relationships between the carbon ages and $\delta^{15} \mathrm{~N}$ values of earthworms, and the carbon utilization of earthworms.

Total soil carbon did not differ significantly among sites (Table 1). However, the biomass of litterfeeding invertebrates was higher in the current broadleaved forest than in the coniferous forest (Table 2), suggesting that current broadleaved forest had more rapid litter input from the O layer to the soil layer. In a 1-yr incubation experiment, Martin (1991) found that aging casts of the endogeic earthworm Millsonia anomala (Megascolecidae, Oligochaeta) retained recalcitrant carbon compounds, and the mineralization rate of carbon in earthworm casts was much lower $\left(3 \% \mathrm{yr}^{-1}\right)$ than that in the control soil without earthworms $\left(11 \% \mathrm{yr}^{-1}\right)$. Wolters (2000) also pointed out that soil invertebrates promote stabilization of SOM. In our results, we did not detect positive effects of earthworms on the rate of SOC accumulation (Table 1), although we did observe a considerable reduction of $\mathrm{O}$ 
layer accumulation. In addition, ${ }^{14} \mathrm{C}$ data across depth intervals suggest that carbon was translocated from the $\mathrm{O}$ layer to the soil layer under broadleaved vegetation by soil invertebrates.

Earthworm activities can have the opposite effects on soil, i.e. they can stabilize SOM or enhance decomposition. For example, in a 127-day microcosm experiment, Wolters and Schaefer (1993) found that an endogeic earthworm, A. caliginosa, enhanced carbon mineralization in beech forest soils. Furthermore, the addition of cellulose regulated the stability of organic carbon in the deep soil layer by stimulating microbial respiration and growth (Fontaine et al. 2007). In this study, in broadleaved forests, litter-feeding earthworms may supply fresh litter continuously to deeper soil layers, resulting in enhancement of microbial decomposition activity. Previous studies based on laboratory experiments showed that earthworms contribute to SOC dynamics (e.g. Martin 1991; Wolters and Schaefer 1993; Wolters 2000). Changes in SOC dynamics are difficult to detect in field conditions even when there is a high biomass of earthworms. This is probably because both positive and negative effects on the turnover of SOC occur simultaneously. Further studies are required to elucidate the long-term effects of soil animals on SOC accumulation under field conditions. These studies would improve our understanding of SOC dynamics.

\section{CONCLUSIONS}

We report, for the first time, both the profiles of SOC and the carbon ages of soil animals based on ${ }^{14} \mathrm{C}$ data. Our results showed that soil ${ }^{14} \mathrm{C}$ profiles differ according to vegetation type and the composition of soil invertebrates. A coniferous forest that has not undergone a vegetation switch showed an isotopic signal close to the atmospheric ${ }^{14} \mathrm{CO}_{2}$ inventory. In contrast, the $\Delta^{14} \mathrm{C}$ values in $\mathrm{BC}, \mathrm{CB}$, and $\mathrm{BB}$ forests were relatively high at all soil depths. These results suggest that the existence of broadleaved forest may be an important factor in SOC mixing because the high biomass of litterfeeding invertebrates in broadleaved forests would provide litter carbon from the $\mathrm{O}$ layer to the soil layer over time.

\section{ACKNOWLEDGMENTS}

We thank H Asano, K Ono, $\mathrm{N}$ Iwashima, and $\mathrm{T}$ Masunaga for their assistance in measuring the weight of soil invertebrates, and M Lucero, M Fukushima, and the staff of the Tomakomai Research Station for their help with field sampling. We thank D Nakano, H Iijima, and 2 reviewers for valuable comments on this manuscript. This work was supported by the Global Environment Research Fund (F-073) by the Ministry of the Environment, Japan and partly by Grant-in-Aid for Young Scientists (A) No. 19681002 from the Japan Society for the Promotion of Science to IT.

\section{REFERENCES}

Berg B, McClaugherty C. 2003. Plant Litter: Decomposition, Humus Formation, Carbon Sequestration. Berlin: Springer Verlag.

Blakemore RJ. 2003. Japanese earthworms (Annelida: Oligochaeta): a review and checklist of species. $\mathrm{Or}$ ganisms Diversity \& Evolution 3(3):241-4.

Bonkowski M, Scheu S, Schaefer M. 1998. Interactions of earthworms (Octolasion lacteum), millipedes (Glomeris marginata) and plants (Hordelymus europaeus) in a beechwood on a basalt hill: implications for litter decomposition and soil formation. Applied Soil Ecology 9(1-3):161-6.

Briones MJI, Garnett MH, Piearce TG. 2005. Earthworm

ecological groupings based on ${ }^{14} \mathrm{C}$ analysis. Soil Biology \& Biochemistry 37(11):2145-9.

Cole DW, Rapp M. 1981. Elemental cycling in forest ecosystems. In: Reichle DE, editor. Dynamic Properties of Forest Ecosystems. New York: Cambridge University Press. p 341-409.

Don A, Steinberg B, Schöning I, Pritsch K, Joschko M, Gleixner G, Schulze E-D. 2008. Organic carbon sequestration in earthworm burrows. Soil Biology \& Biochemistry 40(7):1803-12.

Easton EG. 1981. Japanese earthworms: a synopsis of the megadrile species (Oligochaeta). Bulletin of the British Museum (Natural History) Zoology 40(2):33-65. 
Edwards CA. 1998. Earthworm Ecology. Boca Raton: CRC Press. 389 p.

Eggers T, Jones TH. 2000. You are what you eat...or are you? Trends in Ecology and Evolution 15(7):265-6.

FAO [Food and Agriculture Organization of the United Nations]. 1998. World Reference Base for Soil Resources. Rome: International Soil Reference and Information Centre. $109 \mathrm{p}$.

Fierer N, Strickland MS, Liptzin D, Bradford MA, Cleveland CC. 2009. Global patterns in belowground communities. Ecology Letters 12(11):1238-49.

Fontaine S, Barot S, Barré P, Bdioui N, Mary B, Rumpel C. 2007. Stability of organic carbon in deep soil layers controlled by fresh carbon supply. Nature 450(7167): $277-80$.

Fujiwara Y. 1987. Geologic history of Tomakomai and its surrounding area. Research Bulletin of the College Experiment Forests Hokkaido University 44(2):395404. In Japanese with English summary.

Halaj J, Peck RW, Niwa CG. 2005. Trophic structure of a macroarthropod litter food web in managed coniferous forest stands: a stable isotope analysis with $\delta^{15} \mathrm{~N}$ and $\delta^{13}$ C. Pedobiologia 49(2):109-18.

Hibbard KA, Schimel DS, Archer S, Ojima DS, Parton W. 2003. Grassland to woodland transitions: integrating changes in landscape structure and biogeochemistry. Ecological Applications 13(4):911-26.

Hiura T, Fujiwara K. 1999. Density-dependence and coexistence of conifer and broad-leaved trees in a Japanese northern mixed forest. Journal of Vegetation Science 10(6):843-50.

Hua Q, Barbetti M. 2004. Review of tropospheric bomb ${ }^{14} \mathrm{C}$ data for carbon cycle modeling and age calibration purposes. Radiocarbon 46(3):1273-98.

Hyodo F, Tayasu I, Wada E. 2006. Estimation of the longevity of $\mathrm{C}$ in terrestrial detrital food webs using radiocarbon $\left({ }^{14} \mathrm{C}\right)$ : how old are diets in termites? Functional Ecology 20(2):385-93.

Hyodo F, Tayasu I, Konaté S, Tondoh JE, Lavelle P, Wada E. 2008. Gradual enrichment of ${ }^{15} \mathrm{~N}$ with humification of diets in a below-ground food web: relation between ${ }^{15} \mathrm{~N}$ and diet age determined using ${ }^{14} \mathrm{C}$. Functional Ecology 22(3):516-22.

Igarashi Y. 1987. Vegetational succession in the Tomakomai Experiment Forest Area. Research Bulletin of the College Experiment Forests Hokkaido University 44(2):405-27. In Japanese with English summary.

Ishizuka K. 2001. Taxonomic study of the genus Pheretima s. lat (Oligochaeta, Megascolecidae) from Japan. Bulletin of Seikei University 33(3):1-125.

Jones CG, Lawton JH, Shachak M. 1994. Organisms as ecosystem engineers. Oikos 69(3):373-86.

Kitagawa H, Masuzawa T, Nakamura T, Matsumoto E. 1993. A batch preparation method for graphite targets with low background for $\mathrm{AMS}{ }^{14} \mathrm{C}$ measurements. $\mathrm{Ra}$ diocarbon 35(2):295-300.

Köchy M, Scott DW. 1997. Litter decomposition and ni- trogen dynamics in aspen forest and mixed-grass prairie. Ecology 78(3):732-9.

Körner C. 2000. Biosphere responses to $\mathrm{CO}_{2}$ enrichment. Ecological Applications 10(6):1590-619.

Lavelle P. 1988. Earthworm activities and the soil system. Biology and Fertility of Soils 6(3):237-51.

Lavelle P, Martin A. 1992. Small-scale and large-scale effects of endogeic earthworms on soil organic matter dynamics in soils of the humid tropics. Soil Biology \& Biochemistry 24(12):1491-8.

Lavelle P, Bignell D, Lepage M, Wolters V, Roger P, Ineson P, Heal OW, Dhillion S. 1997. Soil function in a changing world: the role of invertebrate ecosystem engineers. European Journal of Soil Biology 33(4):15993.

Levin I, Kromer B. 2004. The tropospheric ${ }^{14} \mathrm{CO}_{2}$ level in mid-latitudes of the Northern Hemisphere (19592003). Radiocarbon 46(3):1261-72.

Levin I, Hammer S, Kromer B, Meinhardt F. 2008. Radiocarbon observations in atmospheric $\mathrm{CO}_{2}$ : determining fossil fuel $\mathrm{CO}_{2}$ over Europe using Jungfraujoch observations as background. Science of the Total Environment 391(2-3):211-6.

Loranger-Merciris G, Imbert D, Bernhard-Reversat F, Lavelle P, Ponge JF. 2008. Litter N-content influences soil millipede abundance, species richness and feeding preferences in a semi-evergreen dry forest of Guadeloupe (Lesser Antilles). Biology and Fertility of Soils 45(1):93-8.

Martin A. 1991. Short- and long-term effects of the endogeic earthworm Millsonia anomala (Omodeo) (Megascolecidae, Oligochaeta) of tropical savannas, on soil organic matter. Biology and Fertility of Soils 11(3):234-8.

Melillo JM, Aber JD, Muratore JF. 1982. Nitrogen and lignin control of hardwood leaf litter dynamics in forest ecosystems. Ecology 63(3):621-6.

Miyamoto T, Hiura T. 2008. Decomposition and nitrogen release from the foliage litter of fir (Abies sachalinensis) and oak (Quercus crispula) under different forest canopies in Hokkaido, Japan. Ecological Research 23(4):673-80.

Neilson R, Boag B, Smith M. 2000. Earthworm $\delta^{13}$ C and $\delta^{15} \mathrm{~N}$ analyses suggest that putative functional classifications of earthworms are site-specific and may also indicate habitat diversity. Soil Biology \& Biochemistry 32(8-9):1053-61.

Okuzaki Y, Tayasu I, Okuda N, Sota T. 2009. Vertical heterogeneity of a forest floor invertebrate food web as indicated by stable-isotope analysis. Ecological Research 24(6): 1351-9.

Parton WJ, Schimel DS, Cole CV, Ojima DS. 1987. Analysis of factors controlling soil organic matter levels in great plains grasslands. Soil Science Society of America Journal 51(5):1173-9.

Petersen H, Luxton M. 1982. A comparative analysis of soil fauna populations and their role in decomposition 
processes. Oikos 39(3):288-388.

Ponsard S, Arditi R. 2000. What can stable isotopes $\left(\delta^{15} \mathrm{~N}\right.$ and $\left.\delta^{13} \mathrm{C}\right)$ tell about the food web of soil macroinvertebrates? Ecology 81(3):852-64.

R Development Core Team. 2006. A language and environment for statistical computing. Vienna: R Foundation for Statistical Computing.

Sakuma T. 1987. Characterization of soils in the Tomakomai experiment forest. Research Bulletin of the College Experiment Forests Hokkaido University 44(2): 749-59. In Japanese with English summary.

Scharpenseel HW, Becker-Heidmann P, Neue HU, Tsutsuki K. 1989. Bomb-carbon, ${ }^{14} \mathrm{C}$-dating and ${ }^{13} \mathrm{C}-$ measurements as tracers of organic matter dynamics as well as of morphogenetic and turbation processes. Science of the Total Environment 81-82:99-110.

Scheu S. 1987. The role of substrate feeding earthworms (Lumbricidae) for bioturbation in a beechwood soil Oecologia 72(2):192-6.

Scheu S, Falca M. 2000. The soil food web of two beech forests (Fagus sylvatica) of contrasting humus type: stable isotope analysis of a macro- and a mesofaunadominated community. Oecologia 123(2):285-95.

Schimel DS. 1995. Terrestrial ecosystems and the carbon cycle. Global Change Biology 1(1):77-91.

Schmidt O, Scrimgeour CM, Handley LL. 1997. Natural abundance of ${ }^{15} \mathrm{~N}$ and ${ }^{13} \mathrm{C}$ in earthworms from a wheat and a wheat-cover field. Soil Biology \& Biochemistry 29(9-10):1301-8.

Schmidt O, Curry JP, Dyckmans J, Rota E, Scrimgeour CM. 2004. Dual stable isotope analysis $\left(\delta^{13} \mathrm{C}\right.$ and $\delta^{15} \mathrm{~N}$ ) of soil invertebrates and their food sources. $\mathrm{Pe}$ dobiologia 48(2):171-80.

Schröter D, Wolters V, De Ruiter PC. 2003. C and N minerlisation in the decomposer food webs of a European forest transect. Oikos 102(2):294-308

Smith DL, Johnson LC. 2004. Vegetation-mediated changes in microclimate reduce soil respiration as woodlands expand into grasslands. Ecology 85(12): 3348-61.

Stout JD, Goh KM. 1980. The use of radiocarbon to measure the effects of earthworms on soil development. Radiocarbon 22(3):892-6.

Stuiver M, Polach HA. 1977. Discussion: reporting of ${ }^{14} \mathrm{C}$ data. Radiocarbon 19(3):355-63.

Takeda H, Abe T. 2001. Templates of food-habitat resources for the organization of soil animals in temperate and tropical forests. Ecological Research 16(5): 961-73.

Tayasu I, Abe T, Eggleton P, Bignell DE. 1997. Nitrogen and carbon isotope ratios in termites: an indicator of trophic habit along the gradient from wood-feeding to soil-feeding. Ecological Entomology 22(3):343-51.
Tayasu I, Nakamura T, Oda K, Hyodo F, Takematsu Y, Abe T. 2002. Termite ecology in a dry evergreen forest in Thailand in terms of stable $\left(\delta^{13} \mathrm{C}\right.$ and $\left.\delta^{15} \mathrm{~N}\right)$ and radio $\left({ }^{14} \mathrm{C},{ }^{137} \mathrm{Cs}\right.$ and $\left.{ }^{210} \mathrm{~Pb}\right)$ isotopes. Ecological Research 17(2):195-206.

Tiunov AV. 2007. Stable isotopes of carbon and nitrogen in soil ecological studies. Biology Bulletin 34(4):395407.

Toyota A, Kaneko N, Ito MT. 2006. Soil ecosystem engineering by the train millipede Parafontaria laminata in a Japanese larch forest. Soil Biology \& Biochemistry 38(7): 1840-50.

Townsend AR, Vitousek PM, Trumbore SE. 1995. Soil organic matter dynamics along gradients in temperature and land use on the island of Hawaii. Ecology 76(3):721-33.

Trumbore S. 2000. Age of soil organic matter and soil respiration: radiocarbon constraints on belowground C dynamics. Ecological Applications 10(2):399-411.

Trumbore S, Chadwick OA, Amundson R. 1996. Rapid exchange between soil carbon and atmospheric carbon dioxide driven by temperature change. Science 272(5260):393-6.

Uchida M, Shibata Y, Yoneda M, Kobayashi T, Morita M. 2004a. Technical progress in AMS microscale radiocarbon analysis. Nuclear Instruments and Methods in Physics Research B 223-224:313-7.

Uchida T, Kaneko N, Ito MT, Futagami K, Sasaki T, Sugimoto A. 2004b. Analysis of the feeding ecology of earthworms (Megascolecidae) in Japanese forests using gut content fractionation and $\delta^{15} \mathrm{~N}$ and $\delta^{13} \mathrm{C}$ stable isotope natural abundances. Applied Soil Ecology 27(2):153-63.

Wall DH, Bradford MA, John MGS, Trofymow JA, Behan-Pelletier V, Bignell DDE, Dangerfield JM, Parton WJ, Rusek J, Voigt W, Wolters V, Gardel HZ, Ayuke FO, Bashford R, Beljakova OI, Bohlen PJ, Brauman A, Flemming S, Henschel JR, Johnson DL, Jones TH, Kovarova M, Kranabetter JM, Kutny L, Lin KC, Maryati M, Masse D, Pokarzhevskii A, Rahman H, Sabara MG, Salamon JA, Swift MJ, Varela A, Vasconcelos HL, White D, Zou XM. 2008. Global decomposition experiment shows soil animal impacts on decomposition are climate-dependent. Global Change Biology 14(11):2661-77.

Wolters V. 2000. Invertebrate control of soil organic matter stability. Biology and Fertility of Soils 31(1):119 .

Wolters V, Schaefer M. 1993. Effects of burrowing by the earthworm Aporrectodea caliginosa (Savigny) on beech litter decomposition in an agricultural and in a forest soil. Geoderma 56(1-4):627-32. 